\title{
PENGARUH PERCEIVED ORGANIZATIONAL SUPPORT TERHADAP KOMITMEN ORGANISASIONAL DENGAN KEPUASAN KERJA SEBAGAI VARIABEL MEDIASI
}

\author{
Ni Made Anggun Cahayu' ${ }^{1}$ \\ AgoesGanesha Rahyuda ${ }^{2}$
}

\author{
${ }^{1,2}$ FakultasEkonomi dan BisnisUniversitasUdayana (Unud), Bali, Indonesia \\ email:cahayu.anggun@yahoo.com
}

\begin{abstract}
ABSTRAK
Tujuan penelitian ini untuk mengetahui bagaimana peran kepuasan kerjadalam memediasi pengaruh perceived organizational support terhadap komitmen organisasional. Penelitian ini dilakukan di PT Angkasa Pura Hotel In-Flight Catering Tuban. Jumlah sampel yang diambil sebanyak 89 orang karyawan, dengan menggunakan teknik proportionate random sampling. Pengumpulan data diperoleh dari hasil wawancara, observasi dan penyebaran kuesioner. Analisis data menggunakan uji asumsi klasik, analisis jalur path, uji sobel. Berdasarkan hasil analisis ditemukan bahwap erceived organizational support bepengaruh positif dan signifikan terhadap kepuasan kerja. Perceived organizational support berpengaruh positif dan signifikan terhadap komitmen organisasional. Kepuasan kerja berpengaruh positif dan signifikan terhadap komitmen organisasional. Perceived organizational support berpengaruh positif dan signifikan terhadap komitmen organisasional melalui mediasi kepuasan kerja. Upaya meningkatkan rasa komitmen organisasional karyawan, organisasi hendaknya mampu memberikan dukungan kepada karyawannya karena semakin tinggi dukungan yang diberikan kepada karyawan maka semakin tinggi pula kepuasan kerja yang dirasakan oleh karyawan.
\end{abstract}

Kata kunci: perceived organizational support, komitmenorganisasional,kepuasankerja.

\begin{abstract}
The purpose of this study was to determine how the role of job satisfaction in mediating the effect of perceived organizational support on organizational commitment. This research was conducted at PT Angkasa Pura Hotel, In-Flight Catering, Tuban. The number of samples taken were 89 employees, using the proportionate random sampling technique. Data collection was obtained from the results of interviews, observation and questionnaires. Data analysis using classical assumption test, path path analysis, sobel test. Based on the results of the analysis it was found that perceived organizational support had a positive and significant effect on job satisfaction. Perceived organizational support has a positive and significant effect on organizational commitment. Job satisfaction has a positive and significant effect on organizational commitment. Perceived organizational support has a positive and significant effect on organizational commitment through mediating job satisfaction. Efforts to increase employees' sense of organizational commitment, organizations should be able to provide support to their employees because the higher the support given to employees, the higher the job satisfaction felt by employees. Keywords: perceived organizational support, organizational commitment, job satisfaction.
\end{abstract}




\section{PENDAHULUAN}

Perkembangan zaman yang semakinmajuberdampak pada perkembangan jenis usaha dan bisnis salah satunya adalah bidang bisnis food and beverage. Ditambah lagi dengan adanya trend wisata kuliner membuat pertumbuhan bisnis food and beverages semakin memiliki prospek yang baik. Salah satu bagian dari industri food and beverages adalah industri jasa boga. Dimana di dalamnya terdapat restoran, rumah makan, cafe, catering dan lain sebagainya.

Bali merupakan salah satu kawasan yang pertumbuhan industrinya sangat pesat. Berkembangnya industri jasa boga di Bali saat ini disebabkan oleh pertumbuhan ekonomi masyarakat di Bali yang mengarah pada kehidupan metropolis, yang semakin menyebabkan bertambah pula barang dan jasa yang dibutuhkan untuk memenuhi kebutuhannya. Sumber daya manusia sangat dibutuhkan dalam bisnis jasa boga karena merupakan salah satu faktor penentu keberhasilan perusahaan dalam mencapai tujuan perusahaan (Kumara \& Utama, 2016).Untuk mencapai keberhasilan serta mewujudkan tujuan tersebut maka dibutuhkan sumber daya manusia yang memiliki komitmen organisasional yang tinggi pada perusahaan.

Komitmen organisasional sangat penting untuk suatu bisnis karena merupakan dorongan dalam diri individu untuk berbuat sesuatu agar dapat menunjang keberhasilan organisasi dengan tujuan dan lebih mengutamakan kepentingan organisasi. Komitmen organisasional didefinisi kansebagai sikap loyalitas karyawan terhadap organisasi dan ini merupakan proses berkelanjutan yang menunjukkan partisipasi dalam keputusan organisasi dan memiliki keinginan yang kuat untuk mempertahankan keanggotaannya dalam organisasi .(Luthans, 2008). Walaupun komitmen organisasional merupakan hal penting, namun masih banyak terdapat permasalahan komitmen pada suatu perusahaan atau organisasi.

PT Angkasa Pura Hotel In-Flight Catering (APHIC) merupa kan salah satubisnisjasaboga yang merupakanunit dari PT Angkasa Pura Hotel (APH), dimana PT Angkasa Pura Hotel (APH) merupakananakperusahaandari PT Angkasa Pura I (Persero) yang berlokasi di Bandar Udara I GustiNgurah Rai.Berdasarkan data yang didapat pada PT Angkasa Pura Hotel In-Flight Catering terjadi masalah dalam komitmen karyawan, dimana terdapat karyawan yang mengundurkan diri pada setiap bulannya, terlebih pada bulan Desember pada tahun 2017 yang ditunjukkan pada Tabel 1 Data pada Tabel 1. menunjukkan rendahnya komitmen yang dimiliki olehkaryawan pada PT Angkasa Pura Hotel In-Flight Catering. Dari hasil dari wawancara dengan salah satu SDM Ni Wayan Diani Pradnyana yang menyatakan bahwa terjadinya karyawan yang mengundurkan diri karena tidak jelasnya jenjang karir yang didapat oleh karyawan, karyawan berprestasi dalam bekerja tidak pernah mendapat penghargaan dari perusahaan, fasilitas dan tunjangan yang diterima oleh karyawan tergolong rendah dan ketidaksesuaian upah yang diterima oleh karyawan. 
Tabel 1.

Data Karyawan Yang Mengundurkan Diri Dari PT Angkasa Pura Hotel InFlight Catering Tuban

\begin{tabular}{|c|c|c|c|c|c|c|}
\hline No & Nama & Nik & Departemen & Posisi & $\begin{array}{c}\text { Tanggal } \\
\text { Bergabung }\end{array}$ & $\begin{array}{l}\text { Tanggal } \\
\text { Keluar }\end{array}$ \\
\hline 1 & $\begin{array}{l}\text { Komang Kori } \\
\text { Ariawan }\end{array}$ & 201405056 & Operation & $\begin{array}{c}\text { Driver } \\
\text { Handling }\end{array}$ & 1-Dec-14 & $\begin{array}{c}\text { 1-Dec- } \\
17\end{array}$ \\
\hline 2 & I Gede Kartama & 201406037 & Production & $\begin{array}{l}\text { Cook-2 Hot } \\
\text { Kitchen }\end{array}$ & 1-Mar-14 & $\begin{array}{l}\text { 7-Dec- } \\
17\end{array}$ \\
\hline 3 & $\begin{array}{l}\text { I Pt Gede Putra } \\
\text { Yama Yasa }\end{array}$ & 201306006 & Production & $\begin{array}{l}\text { Cook-2 Hot } \\
\text { Kitchen }\end{array}$ & 1-Oct-13 & $\begin{array}{c}\text { 8-Dec- } \\
17\end{array}$ \\
\hline 4 & $\begin{array}{l}\text { Acep Rahmat } \\
\text { Sulaeman }\end{array}$ & 201305001 & Operation & $\begin{array}{l}\text { Operation } \\
\text { Supervisor }\end{array}$ & 1-Oct-13 & $\begin{array}{c}\text { 10-Dec- } \\
17\end{array}$ \\
\hline 5 & Ni Made Arwati & 201503010 & $H R D \& G A$ & Staff GA & 1-Apr-15 & $\begin{array}{c}\text { 15-Dec- } \\
17\end{array}$ \\
\hline 6 & $\begin{array}{l}\text { Ni Made } \\
\text { Okyananta Sari }\end{array}$ & 201508003 & $\begin{array}{c}\text { Sales \& } \\
\text { Marketing }\end{array}$ & Supervisor & 20-Nov-15 & $\begin{array}{c}\text { 20-Dec- } \\
17\end{array}$ \\
\hline 7 & $\begin{array}{l}\text { Benedikta } \\
\text { AntyaYothesta }\end{array}$ & 201608004 & $\begin{array}{c}\text { Sales \& } \\
\text { Marketing }\end{array}$ & Supervisor & $15-F e b-16$ & $\begin{array}{c}\text { 25-Dec- } \\
17\end{array}$ \\
\hline
\end{tabular}

Selain itu, terdapat juga masalah dimana karyawan pada PT Angkasa Pura Hotel In-Flight Catering tidak pernah menghadiri acara yang diselenggarakan oleh PT. Angkasa Pura Hotel In Flight (halal bihalal). Terdapat karyawan PT Angkasa Pura Hotel In-Flight Catering yang tidak mengikuti peraturan yang ditentukan oleh perusahaan seperti keterlambatan atas kehadiran karyawan, terdapat karyawan yang membawa ponsel selama bekerja, mengingat ponsel merupakan salah satu larangan dalam area kerja (kitchen), sering terdapat karyawan laki-laki yang berambut panjang dan berkumis, dan terdapat pelanggaran yang dilakukan oleh karyawan perempuan yang menggunakan bahan kimia seperti cat pada kuku, menginggat PT Angkasa Pura Hotel In-Flight Catering merupakan perusahaan jasa boga dan berstandar dengan Hygiene and Sanatation.

Berdasarkan observasi yang dilakukan, masalah-masalah yang terjadi pada perusahaan tersebut muncul karena kurangnya dukungan organisasi atau yang biasa disebut sebagai perceived organizational support yang diberikan perusahaan pada karyawannya sangat mempengaruhi tinggi atau rendahnya komitmen karyawan PT Angkasa Pura Hotel In-Flight Catering. Perceived Organizational Support (POS) atau persepsi dukungan organisasi merupakan suatu yang dinilai oleh karyawan sebagai anggapan kebutuhan emosisosial, memberikan indikasi dari kesiapan organisasi untuk menghargai peningkatan kerja karyawan, dan mengindikasikan organisasi dalam menyiapkan bantuan saat dibutuhkan untuk mengerjakan suatu pekerjaan yang efektif (Fuller et al., 2003).

Dukungan organisasi sangat berpengaruh positif pada komitmen organisasional, dimana ketika seorang karyawan merasakan sejauh mana organisasi menghargai kontribusi dan pedulit entang kesejahteraan mereka maka akan tumbuh rasa saling memiliki sehingga karyawan akan berkomitmen untuk bertahan serta mewujudkan tujuan dari perusahaan. Hal ini didukung oleh penelitian sebelumnya yang mengemukakan bahwa persepsi dukungan organisasi 
adalah salah satu kunci dalam membangun komitmen yang mengacu pada sejauh mana organisasi menilai kontribusi, memberi dukungan, dan peduli pada kesejahteraan mereka (Rhoades \& Eisenberger, 2002).(Tumwesigye, 2010) menyebutkan komitmen organisasional dapat tercipta karena adanya persepsi dukungan organisasi. Penelitian yang dilakukan oleh Aggarwal-Gupta et al. (2010) menyatakan bahwa persepsi dukungan organisasi berpengaruh positif terhadap komitmen organisasional.

Perceived Organizational Support atau dukungan organisasi juga dapat berpengaruh pada kepuasan kerja, dimana ketika perusahaan memberikan dukungan terhadap karyawan terlebih pada karyawan yang berprestasi serta memberikan feedback yang sesuai dengan kinerja karyawan maka akan timbul rasa kepuasan dalam diri karyawan pada perusahaan. Kepuasan kerja di perlukan untuk memotivasi karyawan agar bekerja secara maksimal. Kepuasan kerja merupakan evaluasi yang menggambarkan seseorang atas perasan sikap senang atau tidak senang, puas atau tidak puas dalam bekerja (Rival \&Jauvani, 2009). (Paillé, Bourdeau, \& Galois, 2010) menjelaskan bahwa perceived organizational support menemukan pengaruh positif terhadap kepuasan kerja. Tingginya persepsi dukungan organisasi yang dirasakan karyawan akan meningkatkan kepuasan kerja pada dirikaryawan (Robbins, 2015).

Kepuasan kerja yang tinggi juga mampu meningkatkan komitmen organisasional, karena semakin tinggi kepuasan kerja yang dirasakan oleh karyawan, maka semakin termotivasi pula karyawan dalam meningkatkan komitmennya bekerja dan begitu pula sebaliknya. Hal inididukung oleh penelitian sebelumnya yang menyatakan adanya pengaruh positif antara kepuasan kerja dengan komitmen organisasional. (Oyewobi et al., 2012) pada penelitian quantity surveyor dalam pelayanan publik nigeria menunjukan bahwa ada korelasi positif antara variabel kepuasan kerja dengan komitmen organisasi. (Hasan, 2012) yang menemukan adanya hubungan positif antara kepuasan kerja dengan komitmen organisasi, serta Jaramillo et al. (2006) menjelaskan ketika karyawan menerima kepuasan dari tempat kerjanya, maka mereka menunjukkan sikap yang menyenangkan terhadap pekerjaannya dan pada akhirnya dapat meningkatkan komitmen mereka terhadap organisasi.

Dalam penjelasan tersebut dapat dilihat bahwa perceived organizational support dapat mempengaruhi tingkat kepuasan kerja dimana semakin tinggi dukungan yang diberikan perusahaan maka semakin tinggi pula kepuasan yang dirasakan oleh karyawan. Kepuasan kerja juga dapat mepengaruhi komitmen organisasional, jika karyawan merasa puas akan feedback yang diberikan oleh perusahaan atas kinerjanya maka semakin tinggi komitmen karyawan terhadap perusahaan. Kepuasan kerja mampu menjadi mediasi antara perceived organizational support terhadap komitmen organisasional. Hal ini didukung oleh penelitan sebelumnya yang menyatakan bahwa seorang karyawan yang merasa puas saat bekerja dengan dukungan perusahaan, maka akan melakukan yang terbaik untuk menyelesaikan pekerjaannya dan berkomitmen pada perusahaannya menurut (Parwita et al., 2013). Menurut (Novira, 2015) persepsi dukungan organisasi yang tinggi akan meningkatkan kepuasan kerja yang dirasakan oleh karyawan dan ketika karyawan merasakan kepuasan kerja yang tinggi karyawan 
akan berusaha untuk melakukan hal yang menguntungkan bagi organisasi. Temuan ini sejalan dengan (Babakus et al., 1996) yang menyatakan bahwa kepuasan kerja memediasi pengaruh dukungan organisasi pada komitmen afektif, komitmen berkelanjutan dan komitmen normatif.

Penelitian (Eisenberger, 2002) menyatakan Persepsi dukungan organisasi sebagai keyakinan global karyawan mengenai sejauh mana organisasi peduli terhadap kesejahteraan mereka dan menghargai kontribusi mereka. (Novira, 2015) dengan adanya rasa peduli organisasi terhadap kesejahteraan karyawan maka akan menimbulkan rasa puas dalam bekerja. (Paillé et al., 2010) menjelaskan bahwa perceived organizational support (POS) pengaruh terhadap kepuasan kerja. Tingginya persepsi dukungan organsasi yang dirasakan karyawan tersebut akan meningkatkan kepuasan kerja pada diri karyawan (Robbins, 2015). Hasil penelitian yang dilakukan, (Filipova, 2011) menyatakan bahwa terdapat hubungan positif dan signifikan antara persepsi dukungan organisasi pada kepuasan kerja. Berdasarkan berbagai hasil penelitian tersebut dapat dikemukakan hipotesis sebagai berikut:

$\mathrm{H}_{1}$ : Perceived Organizational Support berpengaruh positif dan signifikan terhadap Kepuasan Kerja.

Penelitian yang dilakukan oleh Aggarwal-Gupta et al. (2010) menyatakan bahwa persepsi dukungan organisasi berpengaruh positif terhadap komitmen organisasional. Hal ini ditunjukkan dari adanya persepsi dukungan organisasi karyawan sehingga karyawan berkeyakinan tentang nilainya dalam berorganisasi sehingga berdampak dapat memberikan kontribusi untuk organisasi. Penelitian Fernandes et al. (2014) menjelaskan bahwa persepsi dukungan organisasi berpengaruh positif terhadap komitmen organisasional. Penelitian yang dilakukan (Tumwesigye, 2010) menyatakan bahwa persepsi dukungan organisasi berpengaruh positif terhadap komitmen organisasional. (Rhoades \& Eisenberger, 2002) dalam penelitiannya menemukan bahwa POS (Perceived organizational support) memiliki pengaruh positif terhadap komitmen organisasi. Mangun J. (2012) mengatakan bahwa terdapat hubungan yang positif dan signifikan antara dukungan organisasi dengan komitmen organisasional. Berdasarkan hasil penelitian yang telah diuraikan sebelumnya dapat dirumuskan hipotesis sebagai berikut.

$\mathrm{H}_{2}$ : Perceived Organizational Support berpengaruhpositif dan signifikanterhadapKomitmenOrganisasional.

(Oyewobi et al., 2012) pada penelitian quantity surveyor dalam pelayanan publik nigeria menunjukan bahwa ada korelasi positif antara variabel kepuasan kerja dengan komitmen organisasi. Adekola (2012) menunjukan hasil analisis regresi linear berganda yang berhubungan positif antara kepuasan kerja dengan komitmen organisasi. Hasil yang sama juga dinyatakan dalam penelitian yang dilakukan oleh Tania dan Sutanto (2013) bahwa kepuasan kerja memiliki pengaruh positif dan signifikan terhadap komitmen organisasional. Penelitian ini mendukung penelitian De Conmick dan Will (2004) yang menemukan bahwa kepuasan kerja merupakan suatu prediktor yang signifikan terhadap komitmen karyawan pada organisasi. (Ramayah, 2015) dalam penelitiannya menunjukkan bahwa kepuasan kerja yang digambarkan pada kepuasan gaji, promosi, supervisi 
dan kerjasama antar pekerja sangat besar pengaruhnya dalam menentukan komitmen pekerja terhada porganisasi. Ini berarti bahwa semakin tinggi kepuasan kerja yang dirasakan oleh karyawan, maka semakin termotivasi pula karyawan dalam peningkatan komitmen organisasinya (Dana Pramithadkk., 2010). Berdasarkan hasil penelitian yang telah diuraikan sebelumnya dapat dirumuskan hipotesis sebagai berikut.

$\mathrm{H}_{3}$ : Kepuasan Kerja berpengaruh positif dan signifikan terhadap Komitmen Organisasional.

Menurut penelitian (Arshadi \& Hayavi, 2013) ketika organisasi memberi dukungan terhadap karyawan maka karyawan akan menghasilkan kepuasan kerja yang tinggi dan tekad untuk memiliki peran ekstra di luar pekerjaannya. Persepsi dukungan organisasi yang tinggi akan meningkatkan kepuasan kerja yang dirasakan oleh karyawan dan ketika karyawan merasakan kepuasan kerja yang tinggi karyawan akan berusaha untuk melakukan hal yang menguntungkan bagi organisasi. (Novira, 2015) Cara yang dapat ditempuh perusahaan dalam meningkatkan komitmen karyawanya itu dengan meningkatkan kepuasan kerja karyawan. Menurut Handoko (2001:193) kepuasan kerja merupakan keadaan emosional yang menyenangkan atau tidak menyenangkan oleh para karyawan mengenai pekerjaannya. Menurut Parwitadkk. (2013) menyatakan bahwa seorang karyawan yang merasa puas saat bekerja dengan dukungan perusahaan, maka ia akan melakukan yang terbaik untuk menyelesaikan pekerjaannya dan berkomitmen pada perusahaannya. Temuan ini sejalan dengan (Babakus et al., 1996) yang menyatakan bahwa Kepuasan kerja memediasi pengaruh dukungan organisasi pada komitmen afektif dan komitmen continuance dan pada komitmen normatif. Berdasarkan hasil penelitian yang telah diuraikan sebelumnya dapat dirumuskan hipotesis sebagai berikut.

$\mathrm{H}_{4}$ : Kepuasan kerja menjadi mediasi pada hubungan Perceived Organizational Support terhadap Komitmen Organisasional.

\section{METODE PENELITIAN}

Lokasi penelitiandilakukan di PT Angkasa Pura Hotel In-Flight Catering jalan Raya Airport I Gusti Ngurah Rai, Tuban, Kabupaten Badung, Bali. Lokasi tersebut dipilih karena belum banyak yang melakukan penelitian di perusahaan tersebut mengenai sumber daya manusianya. Ditemukan hal-hal yang menyangkut komitmen organisasional dimana diduga tingkat komitmen organisasional dipengaruhi oleh perceived organizational support dengan variabel kepuasan kerja sebagai mediasi.

Populasi dari penelitian ini adalah seluruh karyawan di PT. Angkasa Hotel Pura In-Flight Catering yang berjumlah 114 karyawan yang terdiri dari 3 divisi yaitu 25 orang divisi support, 35 orang divisi operation, dan 54 orang divisi production. Jumlah sampel yang digunakan dalam penelitian ini ditentukan dengan menggunakan pendekatan slovin berdasarkan jumlah populasi PT. Angkasa Pura Hotel In-Flight Catering. Rumus slovin tersebut adalah sebagai berikut:

$$
n=\frac{\mathrm{N}}{1+\mathrm{N} \cdot \mathrm{d}^{2}}
$$


Keterangan :

$$
\begin{aligned}
& \mathrm{n}=\text { Ukuran sampel } \\
& \mathrm{N}=\text { Ukuran populasi } \\
& \mathrm{d}=\text { Nilai kritis (batas ketelitian } 0,05 \text { atau } 5 \% \text { ) }
\end{aligned}
$$

Dengan menggunakan rumus slovin maka akan diperoleh jumlah sampel sebagai berikut :

$$
\begin{gathered}
n=\frac{\mathrm{N}}{1+\mathrm{N}_{\cdot} \mathrm{d}^{2}} \\
n=\frac{114}{1+114(0.05)^{2}} \\
n=88,716=89 \text { (dibulatkan) }
\end{gathered}
$$

Berdasarkan hasil perhitungan diatas maka didapatkan jumlah sampel PT. Angkasa Pura Hotel In-Flight Catering yang akan diambil dalam penelitian ini yaitu sebanyak 89 sampel dengan menggunakan teknik proportionate random sampling yang diambil 20 orang divisi support, 27 orang divisi operation, dan 42 orang divisi production.

Tabel 2.

Populasi dan Sampel Penelitian

\begin{tabular}{lccc}
\hline \multicolumn{1}{c}{ Department } & Populasi & Presentase & Sampel \\
\hline Support & 25 & $21,9 \%$ & 20 \\
Operation & 35 & $30,7 \%$ & 27 \\
Production & 54 & $47,4 \%$ & 42 \\
\multicolumn{1}{c}{ Jumlah } & 114 & $100 \%$ & 89 \\
\hline
\end{tabular}

Sumber:PT. Angkasa Pura Hotel In-Flight Catering, 2017

Pada penelitian ini digunakan teknik analisis data berupa teknik analisis jalur atau disebut sebagai Path Analysis.

Substruktur 1

$$
\mathrm{M}=\mathrm{p} 1 \mathrm{X}+\mathrm{e}_{1}
$$

Keterangan :

$\mathrm{M} \quad=$ Variabel Kepuasan kerja

p1 =Koefisien regresi variabel Perceived Organizational Support pada Kepuasan Kerja

$\mathrm{X}=$ Perceived Organizational Support

$\mathrm{e}_{1} \quad=$ jumlah varian yang tidak diteliti dalam model penelitian

Substruktur 2

$$
\mathrm{Y}=\mathrm{p} 2 \mathrm{X}+\mathrm{p} 3 \mathrm{M}+\mathrm{e}_{2}
$$

Keterangan :

$\mathrm{Y}=$ Variabel komitmen organisasional 
p2 = Koefisien regresi variabel Perceived Organizational Support pada komitmen organisasional

p3 = Koefisien regresi variabel Kepuasan Kerja pada komitmen organisasional

$\mathrm{X}=$ Perceived Organizational Support

$\mathrm{M}=$ KepuasanKerja

$\mathrm{e}_{2}=$ Jumlah varian yang tidak diteliti dalam model penelitian

\section{HASIL DAN PEMBAHASAN}

Penelitian ini menggunakan 89 orang karyawan pada PT Angkasa Pura Hotel In-Flight Catering sebagai responden sesuai dengan ukuran sampel yang digunakan. Penggambaran mengenai responden dalam penelitian ini akan dijelaskan dengan menyajikan karakteristik responden yang didasarkan pada tiga aspek yaitu umur, jenis kelamin dan pendidikan terakhir.

Tabel 3.

Karakteristik Responden PT Angkasa Pura Hotel In-Flight Catering

\begin{tabular}{cccc}
\hline No. & Usia & JumlahResponden (Orang) & PersentaseResponden (\%) \\
\hline 1 & $20-29$ Tahun & 37 & 41,57 \\
2 & $30-39$ Tahun & 29 & 32,58 \\
3 & $40-49$ Tahun & 19 & 21,35 \\
4 & $\geq 50$ Tahun & 4 & 4,50 \\
& Jumlah & $\mathbf{8 9}$ & $\mathbf{1 0 0}$ \\
No. & Jenis Kelamin & JumlahResponden (Orang) & PersentaseResponden (\%) \\
1 & Laki-Laki & 70 & 78,65 \\
2 & Perempuan & 19 & 21,35 \\
& Jumlah & $\mathbf{8 9}$ & $\mathbf{1 0 0}$ \\
No. & Pendidikan Terakhir & JumlahResponden (Orang) & PersentaseResponden (\%) \\
1 & SMA/SMK & 69 & 77,53 \\
2 & Diploma & 12 & 13,48 \\
3 & Sarjana & 8 & 8,99 \\
4 & PascaSarjana & 0 & 0 \\
& Jumlah & $\mathbf{8 9}$ & $\mathbf{1 0 0}$ \\
\hline
\end{tabular}

Sumber: Data diolah, 2018

Tabel 3. menunjukkan terdapat tiga karakteristik responden yaitu usia, jenis kelamin dan pendidikan terakhir. Sebagian besar responden dalam penelitian ini berusia 20 sampai 29 tahun dengan persentase sebesar 41,57\% atau sebanyak 37 orang yang merupakan kelompok dalam usiap roduktif yang mampu bekerja dengan baik. Penelitian ini didominasi dengan responden berjenis kelamin lakilaki dengan persentase sebesar $78,65 \%$ atau 70 orang dan sisanya sebesar $21,35 \%$ atau 19 orang berjenis kelamin perempuan. Pendidikan terakhir responden sebagian besar merupakan lulusan SMA/SMK dengan persentase sebesar 77,53\% atau 69 orang, seseorang yang sudah menempuh pendidikan hingga jenjang SMA diasumsikan memiliki pemahaman dan kemampuan yang cukup baik dalam menyelesaikan pekerjaan. Perhitungan koefisien path dilakukan dengan analisis regresi melalui software SPSS 22.0 for Windows, diperolehhasil yang ditunjukan pada Tabel 4. 
Tabel 4.

Hasil Analisis Jalur 1

\begin{tabular}{lcccc}
\hline \multicolumn{1}{c}{ Variabel } & $\begin{array}{c}\text { Unstandardized } \\
\text { Coefficients }\end{array}$ & $\begin{array}{c}\text { Std. } \\
\text { Error }\end{array}$ & t hitung & Sig. uji t \\
\hline (Constant) & 1,714 & 0,304 & 5,641 & 0,000 \\
Perceived organizational support & 0,569 & 0,078 & 7,320 & 0,000 \\
(X) & & & & \\
R Square & 0,381 & & & \\
Adjusted R Square & 0,374 & & & \\
F Statistik & 53,587 & & & \\
Signifikansi Uji F & 0,000 & &
\end{tabular}

Sumber:Data diolah, 2018

Nilai koefisien regresi variabel perceived organizational support bernilai positif dengan nilai signifikansi uji t kurang dari 0,05 . Hal ini menunjukkan bahwa variabel Perceived organizational support memiliki pengaruh positif yang signifikan terhadap variabel kepuasan kerja. Besarnya pengaruh variabel bebas terhadap variabel terikat yang ditunjukkan oleh nilai determinasi total (Adjusted $\mathrm{R}$ Square) sebesar 0,374 mempunyai arti bahwa sebesar 37,4\% variasi kepuasan kerja di pengaruhi oleh variasi perceived organizational support, sedangkan sisanya sebesar $62,6 \%$ dijelaskan oleh faktor lain yang tidak dimasukkan ke dalam model.

Tabel 5.

Hasil Analisis Jalur 2

\begin{tabular}{lcccc}
\hline \multicolumn{1}{c}{ Variabel } & $\begin{array}{c}\text { Unstandardized } \\
\text { Coefficients }\end{array}$ & $\begin{array}{c}\text { Std. } \\
\text { Error }\end{array}$ & $\begin{array}{c}\text { t } \\
\text { hitung }\end{array}$ & Sig. uji t \\
\hline (Constant) & 0,114 & 0,481 & 0,236 & 0,814 \\
Perceived organizational support & 0,485 & 0,134 & 3,617 & 0,001 \\
X) & & & & \\
Kepuasankerja (M) & 0,451 & 0,145 & 3,107 & 0,003 \\
R Square & 0,408 & & & \\
Adjusted R Square & 0,394 & & & \\
F Statistik & 29,576 & & & \\
Signifikansi Uji F & 0,000 & & & \\
\hline Sumber :Data diati
\end{tabular}

Sumber :Data diolah, 2018

Berdasarkan hasil analisis jalur substruktur 2 seperti yang disajikan pada Tabel 5, maka dapat dibuat persamaan struktural sebagai berikut:

$$
\mathrm{Y}=0,485 \mathrm{X}+0,451 \mathrm{M}+\mathrm{e}_{2}
$$

Nilai koefisien regresi masing-masing variabel bebas bernilai positif dengan nilai signifikansi uji t kurang dari 0,050 . Hal ini menunjukkan bahwa semua variabel bebas memiliki pengaruh positif yang signifikan terhadap variabel terikat. Besarnya pengaruh variabel bebas terhadap variabel terikat yang ditunjukkan oleh nilai determinasi total (Adjusted $\mathrm{R}$ Square) sebesar 0,394 mempunyai arti bahwase besar 39,4\% variasi komitmen organisasional dipengaruhi oleh variasi 
perceived organizational support dan kepuasan kerja, sedangkan sisanya sebesar $60,6 \%$ dijelaskan oleh faktor lain yang tidak dimasukkan ke dalam model.

Berdasarkan model substruktur 1 dan substruktur 2, maka dapat disusun model diagram jalur akhir. Sebelum menyusun model diagram jalur akhir, terlebih dahulu dihitung nilai standar error sebagai berikut:

$$
\begin{aligned}
\mathrm{Pe}_{\mathrm{i}} & =\sqrt{1-\mathrm{R}_{\mathrm{i}}{ }^{2}} \ldots \ldots \ldots \ldots \ldots \ldots \ldots \ldots \ldots \ldots \ldots \ldots \ldots \ldots \ldots \\
\mathrm{Pe}_{1} & =\sqrt{1-R_{1}{ }^{2}}=\sqrt{1-0,374}=0,791 \\
\mathrm{Pe}_{2} & =\sqrt{1-R_{2}{ }^{2}}=\sqrt{1-0,394}=0,778
\end{aligned}
$$

Berdasarkan perhitungan pengaruh error (Pei), didapatkan hasil pengaruh error $\left(\mathrm{Pe}_{1}\right)$ sebesar 0,812 dan pengaruh error $\left(\mathrm{Pe}_{2}\right)$ sebesar 0,746. Hasil koefisien determinasi total adalah sebagai berikut:

$$
\begin{aligned}
\mathrm{R}^{2}{ }_{\mathrm{m}} & =1-\left(\mathrm{Pe}_{1}\right)^{2}\left(\mathrm{Pe}_{2}\right)^{2} \ldots \ldots \\
& =1-(0,791)^{2}(0,778)^{2} \\
& =1-(0,626)(0,605) \\
& =1-0,378=0,622
\end{aligned}
$$

Nilai determinasi total sebesar 0,622 mempunyai arti bahwa sebesar 62,2\% variasi Komitmen organisasional pada PT Angkasa Pura Hotel In-Flight Catering dipengaruhi oleh variasi perceived organizational support dan kepuasan kerja, sedangkan sisanya sebesar $37,8 \%$ djelaskan oleh faktor lain yang tidak dimasukkan kedalam model.

Berdasarkan hasil analisis pengaruh Perceived organizational support terhadap Kepuasan kerja diperoleh nilai Signifikansi sebesar 0,000 dengan nilai koefisien beta 0,569 . Nilai Signifikansi $0,000<0,05$ mengindikasikan bahwa $\mathrm{H}_{0}$ ditolak dan $\mathrm{H}_{1}$ diterima. Hasil ini mempunyai arti bahwa perceived organizational support berpengaruh positif dan signifikan terhadap kepuasan kerja karyawan PT Angkasa Pura Hotel In-Flight Catering.

Berdasarkan hasil analisis pengaruh perceived organizational support terhadap komitmen organisasional diperoleh nilai signifikansi sebesar 0,001 dengan nilai koefisien beta 0,485 . Nilai Signifikansi $0,001<0,05$ mengindikasikan bahwa $\mathrm{H}_{0}$ ditolak dan $\mathrm{H}_{2}$ diterima. Hasil ini mempunyai arti bahwa perceived organizational support berpengaruh positif dan signifikan terhadap komitmen organisasional karyawan PT Angkasa Pura Hotel In-Flight Catering.

Berdasarkan hasil analisis pengaruh kepuasan kerja terhadap komitmen organisasional diperoleh nilai signifikansi sebesar 0,003 dengan nilai koefisien beta 0,451 . Nilai Signifikansi $0,003<0,05$ mengindikasikan bahwa $\mathrm{H}_{0}$ ditolak dan $\mathrm{H}_{3}$ diterima. Hasil ini mempunyai arti bahwa kepuasan kerja berpengaruh positif dan signifikan terhadap komitmen organisasional karyawan PT Angkasa Pura Hotel In-Flight Catering. 
Tabel 6.

Pengaruh Langsung dan Pengaruh Tidak Langsung serta Pengaruh Total Perceived Organizational Support (X), KepuasanKerja (M), dan Komitmen Organisasional (Y)

\begin{tabular}{cccc}
\hline $\begin{array}{c}\text { Pengaruh } \\
\text { Variabel }\end{array}$ & $\begin{array}{c}\text { Pengaruh } \\
\text { Langsung }\end{array}$ & $\begin{array}{c}\text { Pengaruh Tidak Langsung Melalui Kepuasan } \\
\text { kerja } \\
(\mathbf{Y 1})(\boldsymbol{\beta 1} \mathbf{x} \boldsymbol{\beta 3})\end{array}$ & $\begin{array}{c}\text { Pengaruh } \\
\text { Total }\end{array}$ \\
\hline $\mathrm{X} \rightarrow \mathrm{M}$ & 0,569 & - & 0,569 \\
$\mathrm{X} \rightarrow \mathrm{Y}$ & 0,485 & 0,250 & 0,735 \\
$\mathrm{M} \rightarrow \mathrm{Y}$ & 0,451 & - & 0,451 \\
\hline \multicolumn{2}{l}{ Sumber Data diolah, 2018} & &
\end{tabular}

Tabel 6. menunjukkan bahwa pengaruh langsung perceived organizational support terhadap kepuasan kerja adalah sebesar 0,569. Pengaruh langsung variabel perceived organizational support terhadap komitmen organisasional sebesar 0,485. Pengaruh langsung variabel kepuasan kerja terhadap komitmen organisasional sebesar 0,451. Hal ini berarti bahwa variabel komitmen organisasional lebih besar dipengaruhi oleh perceived organizational support dari pada kepuasan kerja. Sedangkan pengaruh tidak langsung variabel perceived organizational support terhadap komitmen organisasional melalui kepuasan kerja karyawan sebesar 0,250. Jadi pengaruh total variabel perceived organizational support terhadap komitmen organisasional melalui kepuasan kerja adalah sebesar 0,735. Jadi dapat disimpulkan bahwa lebih besar total pengaruh perceived organizational support terhadap komitmen organisasional yang melalui kepuasan kerja, dari pada pengaruh langsung perceived organizational support terhadap komitmen organisasional tanpa melalui variabel kepuasan kerja.

Uji sobel merupakan alat analisis untuk menguji signifikansi dari hubungan tidak langsung antara variabel independen dengan variabel dependen yang dimediasi oleh variabel mediator. Uji Sobel dirumuskan dengan persamaan berikut dan dapat dihitung dengan menggunakan aplikasi Microsoft Excel 2007. Bila nilai kalkulasi $\mathrm{Z}$ lebih besar dari 1,96 (dengan tingkat kepercayaan 95 persen), maka variabel mediator dinilai secara signifikan memediasi hubungan antara variabel terikat dan variabel bebas.

Untuk menguji signifikansi pengaruh tidak langsung maka nilai $\mathrm{z}$ dari koefisien ab dihitung dengan rumus sebagai berikut:

$\mathrm{Z}=\frac{a b}{\sqrt{\mathrm{a}^{2} \mathrm{~S}_{\mathrm{b}}{ }^{2}+\mathrm{b}^{2} \mathrm{~S}_{\mathrm{a}}{ }^{2}+\mathrm{S}_{\mathrm{a}}{ }^{2} \mathrm{~S}_{\mathrm{b}}{ }^{2}}} \ldots \ldots \ldots \ldots \ldots \ldots \ldots \ldots \ldots \ldots \ldots \ldots \ldots \ldots \ldots$

$\operatorname{Sig}=(1-\operatorname{NORMDIST}(Z)) 2))$

$$
\begin{array}{lr}
\text { Keterangan: } \\
\mathrm{a}=0,569 \\
\mathrm{~S}_{\mathrm{a}}=0,078 \\
\mathrm{~b}=0,451
\end{array}
$$




$$
\begin{aligned}
& \mathrm{sb} \quad=0,145 \\
& Z=\frac{(0,569)(0,451)}{\sqrt{(0,569)^{2}(0,145)^{2}+(0,451)^{2}(0,078)^{2}+(0,078)^{2}(0,145)^{2}}} \\
& Z=\frac{0,256619}{0,090402} \\
& \mathrm{Z}=2,8386
\end{aligned}
$$

Tabel7.

\section{Hasil Uji Sobel}

\begin{tabular}{rc}
\hline Nilai $\mathbf{Z}$ & Sig \\
\hline 2,8386 & 0,000 \\
\hline Sumber: Data diolah, 2018 &
\end{tabular}

Berdasarkan hasil uji sobel pada Tabel 7. menunjukan bahwa nilai Z hitung sebesar 2,8386>1,96. Artinya Kepuasan kerja (M) merupakan variabel yang memediasi perceived organizational support (X) terhadap komitmen organisasional (Y) karyawan PT Angkasa Pura Hotel In-Flight Catering atau dengan kata lain perceived organizational support berpengaruh secara tidak langsung terhadap komitmen organisasional melalui kepuasan kerja.

Berdasarkan hasil analisis perceived organizational support terhadap Kepuasan Kerja diperoleh nilai Signifikansi sebesar 0,000 dengan nilai koefisien beta 0,569 . Nilai Signifikansi $0,000<0,05$ mengindikasikan bahwa $\mathrm{H}_{0}$ ditolak dan $\mathrm{H}_{1}$ diterima. Hasil ini mempunyai arti bahwa perceived organizational support berpengaruh positif dan signifikan terhadap kepuasan kerja pada PT Angkasa Pura Hotel In-Flight Catering dimana semakin tinggi dukungan organisasi yang diberikan perusahaan maka semakin tinggi kepuasan kerja yang dirasakan karyawan. Hal ini menandakan bahwa perceived organizational support mampu menimbulkan kepuasan kerja pada diri karyawan.

Hasil penelitian ini sesuai dengan hasil penelitian sebelumnya yang dilakukan oleh (Eisenberger, 2002) menyatakan Persepsi dukungan organisasi sebagai keyakinan global karyawan mengenai sejauh mana organisasi peduli terhadap kesejahteraan mereka dan menghargai kontribusi mereka. (Novira, 2015) dengan adanya rasa peduli organisasi terhadap kesejahteraan karyawan makaakan menimbulkan rasa puas dalam bekerja. (Paillé et al., 2010) menjelaskan bahwa perceived organizational support (POS) pengaruh terhadap kepuasan kerja. Tingginya persepsi dukungan organsasi yang dirasakan karyawan tersebut akan meningkatkan kepuasan kerja pada dirikaryawan (Robbins, 2015). Hasil penelitian yang dilakukan, oleh (Filipova, 2011) menyatakan bahwa terdapat hubungan positif dan signifikan antara persepsi dukungan organisasi pada kepuasan kerja.

Hasil pengujian hipotesis pengaruh Perceived Organizational Support terhadap Komitmen Organisasional diperoleh nilai Signifikansi sebesar 0,000 dengan nilai koefisien beta 0,485 . Nilai Signifikansi $0,001<0,05$ mengindikasikan bahwa $\mathrm{H}_{0}$ ditolak dan $\mathrm{H}_{2}$ diterima. Hasil ini mempunyai arti bahwa perceived organizational support berpengaruh positif dan signifikan terhadap komitmen organisasional pada PT Angkasa Pura Hotel In-Flight Catering. Hal ini memiliki 
makna bahwa semakin tinggi dukungan organisasi yang diberikan perushaan kepada karyawan maka akan meningkatkan rasa komitmen organisasional karyawan terhadap perusahaan.

Hasil penelitian ini mendukung temuan dari Aggarwal-Gupta et al. (2010) menyatakan bahwa persepsi dukungan organisasi berpengaruh positif terhadap komitmen organisasional. Hal ini ditunjukkan dari adanya persepsi dukungan organisasi karyawan sehingga karyawan berkeyakinan tentang nilainya dalam berorganisasi sehingga berdampak dapat memberikan kontribusi untuk organisasi. Penelitian Fernandes et al. (2014) menjelaskan bahwa persepsi dukungan organisasi berpengaruh positif terhadap komitmen organisasional. Penelitian yang dilakukan (Tumwesigye, 2010) menyatakan bahwa persepsi dukungan organisasi berpengaruh positif terhadap komitmen organisasional. (Eisenberger, 2002) dalam penelitiannya menemukan bahwa POS (Perceived organizational support) memiliki pengaruh positif terhadap komitmen organisasi. Mangun J. (2012) mengatakan bahwa terdapat hubungan yang positif dan signifikan antara dukungan organisasi dengan komitmen organisasional.

Berdasarkan hasil analisis pengaruh kepuasan kerja terhadap komitmen organisasional diperoleh nilai Signifikansi sebesar 0,003 dengan nilai koefisien beta 0,451 . Nilai Signifikansi $0,000<0,05$ mengindikasikan bahwa $\mathrm{H}_{0}$ ditolak dan $\mathrm{H}_{3}$ diterima. Hasil ini mempunyai arti bahwa kepuasan kerja berpengaruh positif dan signifikan terhadap komitmen organisasional pada PT Angkasa Pura Hotel InFlight Catering. Hal ini memiliki makna bahwa karyawan yang memiliki rasa kepuasan kerja yang tinggi akan dengan sendirinya menimbulkan komitmen dengan ingin tetap berada pada organisasi itu sendiri.

Penelitian ini mendukung beberapa hasil penelitian sebelumnya yang dilakukan oleh (Oyewobi et al., 2012) pada penelitian quantity surveyor dalam pelayanan publik nigeria menunjukan bahwa ada korelasi positif antara variabel kepuasan kerja dengan komitmen organisasi. Adekola (2012) menunjukan hasil analisis regresi linear berganda yang berhubungan positif antara kepuasan kerja dengan komitmen organisasi. Hasil yang sama juga dinyatakan dalam penelitian yang dilakukan oleh Tania dan Sutanto (2013) bahwa kepuasan kerja memiliki pengaruh positif dan signifikan terhadap komitmen organisasional. Penelitian ini mendukung penelitian De Conmick dan Will dalam Widyanti dkk. (2004) yang menemukan bahwa kepuasan kerja merupakan suatu prediktor yang signifikan terhadap komitmen karyawan pada organisasi. (Ramayah, 2015) dalam penelitiannya menunjukkan bahwa kepuasan kerja yang digambarkan pada kepuasan gaji, promosi, supervisi dan kerja sama antar pekerja sangat besar pengaruhnya dalam menentukan komitmen pekerja terhadap organisasi. Ini berarti bahwa semakin tinggi kepuasan kerja yang dirasakan oleh karyawan, maka semakin termotivasi pula karyawan dalam peningkatan komitmen organisasinya dan sebaliknya, semakin rendah kepuasan kerja yang yang dirasakan oleh karyawan, maka semakin karyawan tidak termotivasi untuk meningkatkan komitmen organisasinya (Dana Pramitha dkk., 2010).

Hasil uji menunjukan bahwa nilai $\mathrm{Z}$ hitung sebesar 2,8386 > 1,96 dengan nilai signifikansi $0,000<0,05$, yang artinya kepuasan kerja merupakan variabel yang memediasi perceived organizational support terhadap komitmen organisasi 
pada PT Angkasa Pura Hotel In-Flight Catering atau dengan kata lain kepusan kerja perceived organizational support berpengaruh secara tidak langsung terhadap komitmen organisasional melalui kepuasan kerja. Pengujian sebelumnya menunjukkan pengaruh positif dan signifikan pada pengaruh perceived organizational support terhadap kepuasan kerja, perceived organizational support terhadap komitmen organisasional dan kepuasan kerja terhadap komitmen organisasional, sehingga dapat disimpulkan bahwa kepuasan kerja secara parsial memediasi pengaruh perceived organizational support terhadap komitmen organisasional.

Penelitian ini mendukung beberapa hasil penelitians sebelumnya yang dilakukan oleh (Arshadi \& Hayavi, 2013) ketika organisasi memberi dukungan terhadap karyawan maka karyawan akan menghasilkan kepuasan kerja yang tinggi dan tekad untuk memiliki peran ekstra di luar pekerjaannya. Persepsi dukungan organisasi yang tinggi akan meningkatkan kepuasan kerja yang dirasakan oleh karyawan dan ketika karyawan merasakan kepuasan kerja yang tinggi karyawan akan berusaha untuk melakukan hal yang menguntungkan bagi organisasi. (Novira, 2015) Cara yang dapat ditempuh perusahaan dalam meningkatkan komitmen karyawan yaitu dengan meningkatkan kepuasan kerja karyawan. Menurut Handoko (2001:193) kepuasan kerja merupakan keadaan emosional yang menyenangkan atau tidak menyenangkan oleh para karyawan mengenai pekerjaannya. Menurut Parwita dkk. (2013) menyatakan bahwa seorang karyawan yang merasa puas saat bekerja dengan dukungan perusahaan, maka ia akan melakukan yang terbaik untuk menyelesaikan pekerjaannya dan berkomitmen pada perusahaannya. Temuan ini sejalan dengan (Babakus et al., 1996) yang menyatakan bahwa kepuasan kerja memediasi pengaruh dukungan organisasi pada komitmen afektif dan komitmen continuance dan pada komitmen normatif.

Hasil penelitian ini mendukung teori yang digunakan sebagai dasar dalam pembuatan hipotesis bahwa perceived organizational support mempengaruhi komitmen organisasional, selain itu peran kepuasan kerja mampu memediasi hubungan perceived organizational support terhadap komitmen organisasional. Ketika karyawan merasa mendapat dukungan dari organisasi dan disertai dengan kepuasan kerja yang tinggi, maka akan dapat meningkatkan komitmen organisasional. Hal ini menunjukan bahwa hasil penelitian memperkuat teori yang digunakan.

Teori yang digunakan dalam penelitian ini adalah Social Exchange Theory atau teori pertukaran sosial. Berdasarkan hasil pengujian sebelumnya, bahwa teori pertukuran sosial terdukung dalam penelitian ini, karena semua hipotesis berpengaruh positif dan signifikan. Pertukaran dapat terjadi apabila dua belah pihak antara karyawan dan organisasi mampu memberikan sesuatu hal satus ama lain. Maka dari itu, karyawan akan memberikan extra-role ketika mereka telah diperlakukan dengan baik oleh organisasi, dan mereka akan cenderung untuk besikap dan berperilaku lebih positif terhadap organisasi.

Implikasi hasil penelitian ini memfokuskan pada kegunaan dan manfaat dari hasil penelitian untuk meningkatkan Komitmen Organisasional pada karyawan PT Angkasa Pura Hotel In-Flight Catering melalui dukungan organisasi dan kepuasan kerja. Penelitian ini juga diharapkan mampu menjadi pertimbangan 
dalam mengambil keputusan sehingga mampu mengurangi resiko timbulnya permasalahan yang akan terjadi. Jika PT Angkasa Pura Hotel In-Flight Catering mampu memberikan dukungan organisasi kepada karyawannya seperti memberikan motivasi maka akan timbul rasa kekeluargaan dalam diri karyawan sehingga karyawan akan memiliki komitmen organisasional yang tinggi untuk tetap mempertahankan keanggotannya pada PT Angkasa Pura Hotel In-Flight Catering dan karyawan akan merasakan kepuasan dalam bekerja dan membantu PT Angkasa Pura Hotel In-Flight Catering untuk mencapai tujuannya. Dalam hal ini hasil penelitian ini secara praktis digunakan sebagai bahan pertimbangan kebutuhan karyawan.

\section{SIMPULAN}

Perceived organizational support berpengaruh positif dan signifikan terhadap kepuasan kerja pada PT Angkasa Pura Hotel In-Flight Catering. Perceived organizational support berpengaruh positif dan signifikan terhadap komitmen organisasional pada PT Angkasa Pura Hotel In-Flight Catering. Kepuasan kerja berpengaruh positif dan signifikan terhadap komitmen organisasional pada PT Angkasa Pura Hotel In-Flight Catering. Kepuasan kerja merupakan variabel yang memediasi perceived organizational support terhadap komitmen organisaional pada PT Angkasa Pura Hotel In-Flight Catering.

PT Angkasa Pura Hotel In-Flight Catering sebaiknya lebih memperhatikan setiap keluhan yang dirasakan karyawan dengan cara memberikan dukungan kepada karyawan serta menghargai kontribusi atas kinerja karyawan sehingga akan menimbulkan rasa kebermaknaan serta perasaan senang dan karyawan merasa dianggap penting oleh perusahaan. PT Angkasa Pura Hotel In-Flight Catering sebaiknya memperhatikan gaya kepemimpinan seperti bersikap tegas dan adil kepada karyawan dan membantu memberi petunjuk mengenai kegiatan perusahaan sehingga kepuasan kerja akan terus berada pada titik terbaik dimana secara langsung akan mempengaruhi kinerja karyawan pada perusahaan. Upaya meningkatkan komitmen organisasional karyawan pada PT Angkasa Pura Hotel In-Flight Catering, perusahaan harus mampu membuat karyawan berkeinginan untuk menghabiskan sisa karirnya dengan tetap berada pada perusahaan karena karyawan merupakan aset yang paling penting dalam menajalankan suatu perusahaan.

\section{REFERENSI}

Arshadi, N., \& Hayavi, G. (2013). The Effect of Perceived Organizational Support on Affective Commitment and Job Performance: Mediating Role of OBSE. Procedia - Social and Behavioral Sciences. https://doi.org/10.1016/j.sbspro.2013.06.637

Babakus, E., Cravens, D. W., Johnston, M., \& Moncrief, W. C. (1996). Examining the role of organizational variables in the salesperson job satisfaction model. Journal of Personal Selling and Sales Management. https://doi.org/10.1080/08853134.1996.10754062 
Eisenberger, R. (2002). Reaprocation of Perceived Organizational Support. Journal of Applied Psychology, 86(1).

Filipova. (2011). Relationship among ethical Climates Perceived Organzatonal Support and Intent to Leave for Licensed Nurses and Skilled Nursing Facilities. Journal of Applied Gerontology, 20(10), 1-23.

Fuller, J. B., Barnett, T., Hester, K., \& Relyea, C. (2003). A social identity perspective on the relationship between perceived organizational support and organizational commitment. Journal of Social Psychology. https://doi.org/10.1080/00224540309600432

Hasan, L. (2012). Pengaruh Kepuasan Kerja dan Displin terhadap Komitmen Organisasi Pegawai Dinas Perindustrian Perdagangan Perambangan dan Energi Kota Padang. Jurnal Manajemen Dan Kewirausahaan, 3(1), 20865031 .

Kumara, I. W. S. E., \& Utama, I. W. M. (2016). PENGARUH PELATIHAN TERHADAP KINERJA KARYAWAN DENGAN MEDIASI KEPEMIMPINAN PADA HOTEL SATRIYA COTTAGES KUTA-BALI. E-Jurnal Manajemen Unud. https://doi.org/10.1111/1365-2664.12938

Luthans, F. (2008). Organizational behavior. United satates. McGraw-Hill.

Novira, L. dan S. M. (2015). Pengaruh persepsi dukungan organisasi pada perilaku kewargaan organsasional dengan kepuasan kerja sebagai variabel intervening. Management Analysis Journal, 4(3), 181-188.

Oyewobi, L. O., Suleiman, B., \& Muhammad-Jamil, A. (2012). Job Satisfaction and Job Commitment: A Study of Quantity Surveyors in Nigerian Public Service. International Journal of Business and Management. https://doi.org/10.5539/ijbm.v7n5p179

Paillé, P., Bourdeau, L., \& Galois, I. (2010). Support, trust, satisfaction, intent to leave and citizenship at organizational level: A social exchange approach. International Journal of Organizational Analysis. https://doi.org/10.1108/19348831011033203

Parwita, Gde Bayu Surya, I. W. G. S. dan P. S. (2013). Pengaruh Kepuasan Kerja terhadap Komitmen Organisasi dan Disiplin Kerja. E-Jurnal Ekonomi Dan Bisnis Universitas Udayana, 2(11), 737-760.

PT Angkasa Pura Hotel In-Flight Catering Tuban. (n.d.). Data Perusahaan (2017) dan (2018).

Ramayah, T. A. M. N. (2015). Job satisfaction and organizational commitment: differential effects ror men and women. Jurnal Manajemen Dan Bisnis, 5(1), 75-90. 
Rhoades, L., \& Eisenberger, R. (2002). Perceived organizational support: A review of the literature. Journal of Applied Psychology. https://doi.org/10.1037/0021-9010.87.4.698

Robbins, S. P. dan T. A. J. (2015). Perilaku Organisasi Edisi 16 terjemahan. Jakarta: Salemba Empat.

Tumwesigye, G. (2010). (Not helping much)The relationship between perceived organisational support and turnover intentions in a developing country: The mediating role of organisational commitment. Africal Journal of Business Management. 